Supplement of Atmos. Chem. Phys., 18, 6625-6635, 2018

https://doi.org/10.5194/acp-18-6625-2018-supplement

(C) Author(s) 2018. This work is distributed under

the Creative Commons Attribution 4.0 License.

(c) (1)

Supplement of

\title{
Mass spectrometric measurement of hydrogen isotope fractionation for the reactions of chloromethane with $\mathrm{OH}$ and $\mathrm{Cl}$
}

Frank Keppler et al.

Correspondence to: Frank Keppler (frank.keppler@geow.uni-heidelberg.de)

The copyright of individual parts of the supplement might differ from the CC BY 4.0 License. 
Table S1: Experimental details for the degradation of chloromethane and methane with $\mathrm{OH}$ radicals

\begin{tabular}{|c|c|c|c|c|c|c|c|c|c|}
\hline Exp. & date & reaction & $\begin{array}{l}\text { initial } \\
\text { mixing } \\
\text { ratio } \\
\text { ppmv }\end{array}$ & $\begin{array}{c}\text { Ozone } \\
\text { photolysis } \\
\text { TUV lamp }\end{array}$ & $\begin{array}{c}\text { steady state } \\
\mathrm{O}_{3} \text { mixing } \\
\text { ratio } \\
\text { ppbv }\end{array}$ & $\begin{array}{c}\text { relative } \\
\text { humidity } \\
\% \\
\%\end{array}$ & $\begin{array}{c}\underset{\mathrm{H}_{2}}{\mathrm{H}_{2}} \\
\text { ppmv }\end{array}$ & $\begin{array}{l}\mathrm{T} \\
{ }^{\circ} \mathrm{C}\end{array}$ & $\begin{array}{l}\mathrm{OH} \\
\mathrm{cm}^{-3}\end{array}$ \\
\hline $1 \& 2$ & $25 / 04 / 2014$ & $\mathrm{CH}_{3} \mathrm{Cl}+\mathrm{OH}$ & 5,10 & $1 \times 55 W$ & 620 & 65 & 2000 & 20.7 & $2.9 \times 10^{9}$ \\
\hline $\begin{array}{c}3 \\
\text { blank }\end{array}$ & $\begin{array}{l}03 / 02 / 2015 \\
01 / 02 / 2015\end{array}$ & $\begin{array}{c}\mathrm{CH}_{3} \mathrm{Cl}+\mathrm{CH}_{4}+\mathrm{OH} \\
\mathrm{CH}_{4}\end{array}$ & $\begin{array}{c}10+5 \\
5\end{array}$ & $4 \times 55 W$ & 3570 & $\begin{array}{l}65 \\
72\end{array}$ & 2000 & $\begin{array}{l}20.4 \\
20.3\end{array}$ & $1.6 \times 10^{10}$ \\
\hline 4 & $02 / 02 / 2015$ & $\mathrm{CH}_{4}+\mathrm{OH}$ & 6 & $4 \times 55 W$ & 3570 & 75 to72 & & 20.3 & $1.6 \times 10^{10}$ \\
\hline control & $02 / 02 / 2015$ & $\mathrm{CH}_{4}+\mathrm{OH}$ & 5 & $4 \times 55 W$ & 5000 & 72 & & 20.3 & $2.0 \times 10^{10}$ \\
\hline
\end{tabular}

\section{Generation of hydroxyl radicals and control measurements for potential loss effects}

In our study, $\mathrm{OH}$ was generated by UV-photolysis of ozone in the presence of water vapour. This is a well-established efficient method for $\mathrm{OH}$ radical generation (Cantrell et al. 1990, DeMore 1992). In order to perform the degradation experiments within a day, the experimental conditions, in particular the radiation intensity and the ozone concentration, were modified for the different experiments as indicated in Table S1. Based on the high radiant efficiency of the TUV lamp at the absorption band of $\mathrm{O}_{3}$, the photolysis of $\mathrm{O}_{3}$ to $\mathrm{O}\left({ }^{1} \mathrm{D}\right)$ and $\mathrm{O}_{2}$ and the subsequent generation of $\mathrm{OH}$ in the reaction $\mathrm{O}\left({ }^{1} \mathrm{D}\right)+\mathrm{H}_{2} \mathrm{O}$ are favoured. One can estimate a photolysis rate of $\mathrm{J}\left(\mathrm{O}_{3}\right)$ in the range of $10^{-3} \mathrm{~s}^{-1}$ for the first experiment with $\mathrm{CH}_{3} \mathrm{Cl}$. For the $\mathrm{CH}_{4}$ experiments we had 4 TUV lamps installed around the chamber, which increased the $\mathrm{J}\left(\mathrm{O}_{3}\right)$ value. This is confirmed by the reduced lifetime of $\mathrm{O}_{3}$ when the lamps are on and no $\mathrm{O}_{3}$ is injected (roughly $11 \mathrm{~min}$ for the $\mathrm{CH}_{3} \mathrm{Cl}+\mathrm{OH}$ experiment and 4 min for the $\mathrm{CH}_{4}+\mathrm{OH}$ experiment).

During the first two experiments $\left(\mathrm{CH}_{3} \mathrm{Cl}+\mathrm{OH}\right)$, the steady state mixing ratios of ozone during photolysis were about 620 ppbv for $9 \mathrm{~h}$. Ozone photolysis was carried out with one 55W TUV lamp at a relative humidity of $65 \%$. During the fourth experiment $\left(\mathrm{CH}_{4}+\mathrm{OH}\right)$ with four TUV lamps, the steady state ozone mixing ratio was $3570 \mathrm{ppbv}$ for $13 \mathrm{~h}$ and the relative humidity was $75 \%$ making a higher $\mathrm{OH}$ concentration reasonable. Mean $\mathrm{OH}$ concentrations present for the $\mathrm{CH}_{3} \mathrm{Cl}$ and $\mathrm{CH}_{4}$ in these experiments were $2.9 \times 10^{9} \mathrm{~cm}^{-3}$ and $1.6 \times 10^{10} \mathrm{~cm}^{-3}$, respectively The reaction rate constant at $293 \mathrm{~K}$ for $\mathrm{CH}_{3} \mathrm{Cl}+\mathrm{OH}\left(3.3 \times 10^{-14} \mathrm{~cm}^{-3}\right.$, Burkholder et al., 2015) is roughly 6 times higher than that for $\mathrm{CH}_{4}\left(5.7 \times 10^{-15} \mathrm{~cm}^{-3}\right.$, Burkholder et al., 2015). Considering the adjusted conditions, the lifetime of $\mathrm{CH}_{3} \mathrm{Cl}$ in experiment one and two should roughly be the same as that of $\mathrm{CH}_{4}$ in experiment four. Finally, the third experiment $\left(\mathrm{CH}_{3} \mathrm{Cl}+\mathrm{CH}_{4}+\mathrm{OH}\right)$ was carried out under similar conditions as the fourth experiment but at a relative humidity of $65 \%$ and thus a lower $\mathrm{OH}$ yield as compared to the fourth experiment. Moreover, the initial mixing ratios of $\mathrm{CH}_{3} \mathrm{Cl}$ and $\mathrm{CH}_{4}$ in experiment 3 were 10 and $5 \mathrm{ppmv}$, respectively. Considering the adjusted conditions, the lifetime of $\mathrm{CH}_{3} \mathrm{Cl}$ in experiment 3 should roughly be the same as that of $\mathrm{CH}_{4}$ in experiment 4. Finally the observed loss rate of $\mathrm{CH}_{3} \mathrm{Cl}$ was 5.8 times faster than the observed loss rate for $\mathrm{CH}_{4}$, being in line with the ratio of the reported rate constants.

During all these degradation experiments, ozone and UV were turned off from time to time to take the canister samples (see Figure S3). In order to estimate the $\mathrm{OH}$ yield in this experiment, a further $\mathrm{CH}_{4}$ degradation experiment was carried out (control experiment Table S1, Figure S2). During this experiment, ozone was photolyzed continuously and we only measured the mixing ratios of $\mathrm{CH}_{4}$ and $\mathrm{CO}_{2}$ and did not take any canister samples. The 
mean $\mathrm{OH}$ concentration during continuous ozone photolysis in this experiment was $1.7 \times 10^{10}$ $\mathrm{cm}^{-3}$. We also performed a blank experiment prior to the $\mathrm{CH}_{4}+\mathrm{OH}$ experiment to address unaccounted losses such as diffusion of $\mathrm{CH}_{4}$ through the FEP foil. During all experiments with $\mathrm{CH}_{4}$, we used $\mathrm{CO}_{2}$ as an inert tracer to correct for dilution effects. The $\mathrm{CH}_{4}$ and $\mathrm{CO}_{2}$ mixing ratios were determined with a Picarro G221i cavity ring down spectrometer. Prior to the experiments, the instrument was calibrated with pressurized air from a tank obtained from the Max-Planck-Institute for Biogeochemistry in Jena/Germany.

The blank experiment was carried out with a dilution flow of $4 \mathrm{~L} \mathrm{~min}{ }^{-1}$. The measured mixing ratios were corrected for the respective blanks of the zero air that were $<0.01 \mathrm{ppmv}$ for methane and 8.2 \pm 0.2 ppmv for $\mathrm{CO}_{2}$. The measured $\mathrm{CH}_{4}$ and $\mathrm{CO}_{2}$ mixing ratios as well as the dilution corrected $\mathrm{CH}_{4}$ mixing ratios are shown in Figure $\mathrm{S} 1$. The slope for $\mathrm{CH}_{4}$ and $\mathrm{CO}_{2}$ were $-0.00118 \mathrm{~min}^{-1}$ and $0.00117 \mathrm{~min}^{-1}$ respectively. This corresponds to a dilution flow of $4.1 \pm 0.1 \mathrm{~L} \mathrm{~min}{ }^{-1}$, which is in good agreement with the pre-set dilution flow (the major uncertainty in this calculation is the exact volume of the chamber). During this blank experiment, the dilution corrected mixing ratio of $\mathrm{CH}_{4}$ changed by less than $0.2 \%$. We can thus safely rule out any unaccounted losses of $\mathrm{CH}_{4}$.

The measured $\mathrm{CH}_{4}$ and $\mathrm{CO}_{2}$ mixing ratios as well as the dilution corrected mixing ratios from the $\mathrm{CH}_{4}$ control experiment are shown in Figure S2. The upper panel of figure S3 shows the respective results from the $\mathrm{CH}_{4}+\mathrm{OH}$ isotope fractionation experiment (exp.4 in Table S1) and the lower panel shows the corresponding $\mathrm{O}_{3}$ mixing ratios. For this experiment the dilution flow was reduced initially to $0.6 \mathrm{~L} \mathrm{~min}$.- During this experiment, it was necessary to stepwise increase the dilution flow for maintaining an overpressure of $0.5 \mathrm{hPa}$ inside the chamber. This resulted in a non-exponential loss due to dilution as shown in the $\mathrm{CO}_{2}$ mixing ratios.

Further discussion regarding the differences between the experimental and analytical design and protocols of the study by Sellevåg et al. (2006) and this study (Keppler et al. 2018)

One potential source of error is incomplete mixing inside the chamber. Incomplete mixing may result in an underestimation of the KIE due to transport limitation. The experiments of Sellevåg et al. (2006) were carried out in a 250L electropolished stainless steel chamber, whereas our experiments were carried out in a 3500L Teflon-FEP chamber. Hence incomplete mixing might be an issue for our set up. However, the lifetime of $\mathrm{CH}_{3} \mathrm{Cl}$ under the experimental conditions employed in our studies was in the order of 6 to 10h, whereas the turnover of air inside the chamber occurred on time scales of a few minutes, thus making incomplete mixing an unlikely source of error. Incomplete mixing would also have affected the determination of the respective $\mathrm{KIEs}$ for $\mathrm{CH}_{4}$. Since our reported values are in reasonable agreement with previously reported KIEs we consider incomplete mixing as a potential source of error in our experiments to be highly unlikely.

The chlorine radical generation scheme appears to be quite similar for both studies. Sellevåg et al. (2006) used narrowband photolysis of molecular chlorine employing a Philips TLD-08 flourescent lamp ( $\left.\lambda_{\max } \sim 370\right) \mathrm{nm}$ whereas we used broadband photolysis (300 to $700 \mathrm{~nm}$ ). Both are well established methods.

In the Sellevåg et al. (2006) study, $\mathrm{OH}$ was generated under dry conditions from the UVphotolysis of ozone (300 to 500 ppmv) in the presence of 2000 ppmv of $\mathrm{H}_{2}$. In our study, ozone was photolyzed at a level of typically $0.5-10 \mathrm{ppmv}$ in the presence of water vapour $(\mathrm{RH}$ of about $70 \%)$ and 2000 ppmv of $\mathrm{H}_{2}$ to generate $\mathrm{OH}$. The reaction rate constants of 
$\mathrm{O}\left({ }^{1} \mathrm{D}\right)$ with $\mathrm{H}_{2}$ and $\mathrm{H}_{2} \mathrm{O}$ at $298 \mathrm{~K}$ are $1.1^{*} 10^{-10}$ and $2.2 * 10^{-10} \mathrm{~cm}^{3} \mathrm{~s}^{-1}$, respectively (Burkolder et al., 2015) . At a relative humidity of $70 \%$ (corresponding to 25000 ppmv of $\mathrm{H}_{2} \mathrm{O}$ at $20^{\circ} \mathrm{C}$ ), the reaction with $\mathrm{H}_{2} \mathrm{O}$ is by far the main pathway to form $\mathrm{OH}$ (with the $\mathrm{H}_{2}$ pathway contributing less than $1 \%$ to the $\mathrm{OH}$ yield). Thus, in the absence of water vapour, the half-life of $\mathrm{CH}_{3} \mathrm{Cl}$ can be estimated to about $600 \mathrm{~h}$. This is consistent with previous studies, where ozone levels of 500 to 600 ppmv were required for a sufficient $\mathrm{OH}$ production from $\mathrm{H}_{2}$ (Gola et al. 2005, Sellevåg et al. 2006). In our study, photolysis of 2 ppmv ozone in the absence of water vapour $(\mathrm{RH}<1 \%)$ but with 2000 ppmv $\mathrm{H}_{2}$ resulted in a $\mathrm{CH}_{3} \mathrm{Cl}$ degradation of less than $3 \%$ over 10 hours because of the insufficient $\mathrm{OH}$ yield. With this, we can safely exclude any measurable effect from potential side reactions on the determination of the KIEs.

Additionally, we monitored the ratio of $\mathrm{CH}_{3} \mathrm{Cl}$ and $\mathrm{PFH}$ for at least $2 \mathrm{~h}$ prior to each experiment to assess potential side reactions. For the experiments with chlorine, this was done under dark conditions in the presence of $10 \mathrm{ppmv} \mathrm{Cl}_{2}$. For the $\mathrm{OH}$ experiments, this was either done in the absence of light or ozone. None of these tests revealed any indication of a measurable degradation of $\mathrm{CH}_{3} \mathrm{Cl}$ thus excluding any bias due to side reactions.

Cantrell et al. (1990), who used UV-photolysis in the presence of water as an $\mathrm{OH}$ source, estimated that the reaction of $\mathrm{CH}_{4}$ with $\mathrm{O}\left({ }^{1} \mathrm{D}\right)$ may contribute about $3 \%$ to the overall degradation. The higher ozone levels and the less efficient conversion of $\mathrm{O}\left({ }^{1} \mathrm{D}\right)$ to $\mathrm{OH}$ in the Sellevåg et al. (2006) study suggest an overall higher transient $O\left({ }^{1} D\right)$ concentration as compared to our experiments. However the $\mathrm{KIE}$ for the reaction of $\mathrm{CH}_{4}$ with $\mathrm{O}\left({ }^{1} \mathrm{D}\right)$ is 1.060 (Saueressig et al. 2001) and thus substantially smaller than the respective KIE for the reaction with $\mathrm{OH}$. When assuming a similar trend for the reactions of $\mathrm{CH}_{3} \mathrm{Cl}$, one would expect an underestimation of the $\mathrm{KIE}$ for the reaction of $\mathrm{CH}_{3} \mathrm{Cl}$ with $\mathrm{OH}$ in the Sellevåg experiments. Since the KIE reported by Sellevåg et al. (2006) was larger than that determined in our study any side effect from this reaction is unlikely.

\section{References:}

Burkholder, J.B. et al. Chemical Kinetics and Photochemical Data for Use in Atmospheric Studies, Evaluation No. 18," JPL Publication 15-10, Jet Propulsion Laboratory, Pasadena, http://jpldataeval.jpl.nasa.gov, 2015.

Cantrell, C. A., Shetter, R. E., McDaniel, A. H., Calvert, J. G., Davidson, J. A., Lowe, D. C., Tyler, S. C., Cicerone, R. J., and Greenberg, J. P.: Carbon kinetic isotope effect in the oxidation of methane by the hydroxyl radical, J. Geophys. Res., 95, 2245522462, doi:10.1029/JD095iD13p22455, 1990.

DeMore, W. B.: Rate constant ratio for the reaction of $\mathrm{OH}$ with $\mathrm{CH}_{3} \mathrm{D}$ and $\mathrm{CH}_{4}, \mathrm{~J}$. Phys. Chem., 97, 8564-8566, 1993.

Gola, A. A., D'Anna, B., Feilberg, K. L., Sellevåg, S. R., Bache-Andreassen, L., and Nielsen, C. J.: Kinetic isotope effects in the gas phase reactions of $\mathrm{OH}$ and $\mathrm{Cl}$ with $\mathrm{CH}_{3} \mathrm{Cl}$, $\mathrm{CD}_{3} \mathrm{Cl}$, and $\left(\mathrm{CH}_{3} \mathrm{Cl}\right)-\mathrm{C}-13$, Atmos. Chem. Phys., 5, 2395-2402, 2005.

Saueressig, G. et al. Carbon 13 and D kinetic isotope effects in the reactions of $\mathrm{CH}_{4}$ with $\mathrm{O}\left({ }^{1} \mathrm{D}\right)$ and $\mathrm{OH}$ : New laboratory measurements and their implications for the isotopic composition of stratospheric methane. Journal of Geophysical Research: Atmospheres 106, 23127-23138, doi:10.1029/2000JD000120, 2001.

Sellevåg, S. R., Nyman, G., and Nielsen, C. J.: Study of the Carbon-13 and Deuterium Kinetic Isotope Effects in the $\mathrm{Cl}$ and $\mathrm{OH}$ Reactions of $\mathrm{CH}_{4}$ and $\mathrm{CH}_{3} \mathrm{Cl}$, J. Phys. Chem. 110, 141-152, 2006. 
Figures S1-S3

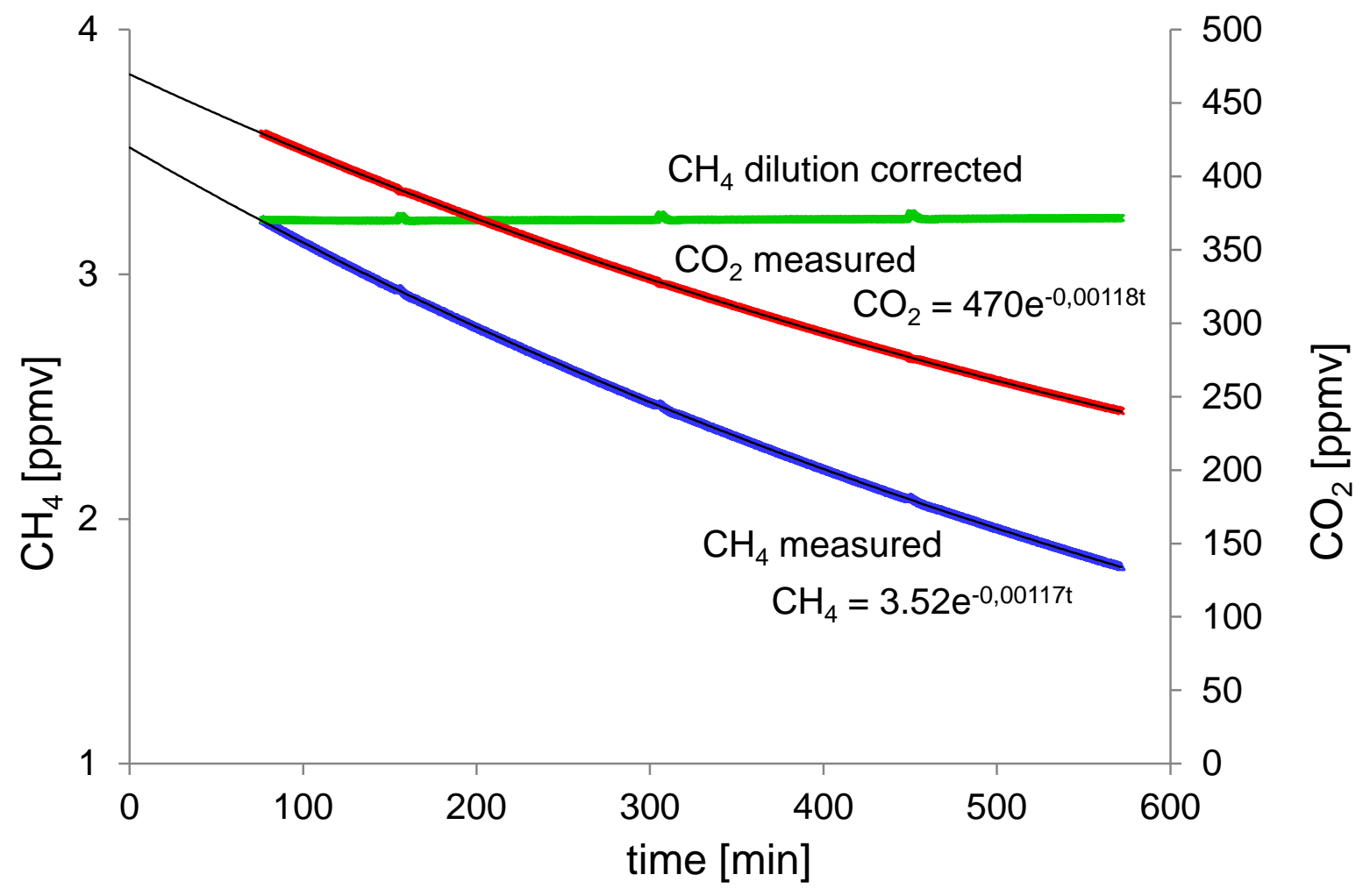

Figure S1: Methane blank experiment without ozone and $\mathrm{OH}$. The blue and red lines show the measured $\mathrm{CH}_{4}$ and $\mathrm{CO}_{2}$ mixing ratios, respectively. The green line shows the dilution corrected $\mathrm{CH}_{4}$ mixing ratios using $\mathrm{CO}_{2}$ as inert tracer. The dilution corrected $\mathrm{CH}_{4}$ mixing ratio changed from $3.22 \mathrm{ppmv}$ at the beginning to $3.23 \mathrm{ppmv}$ at the end of the experiment. 


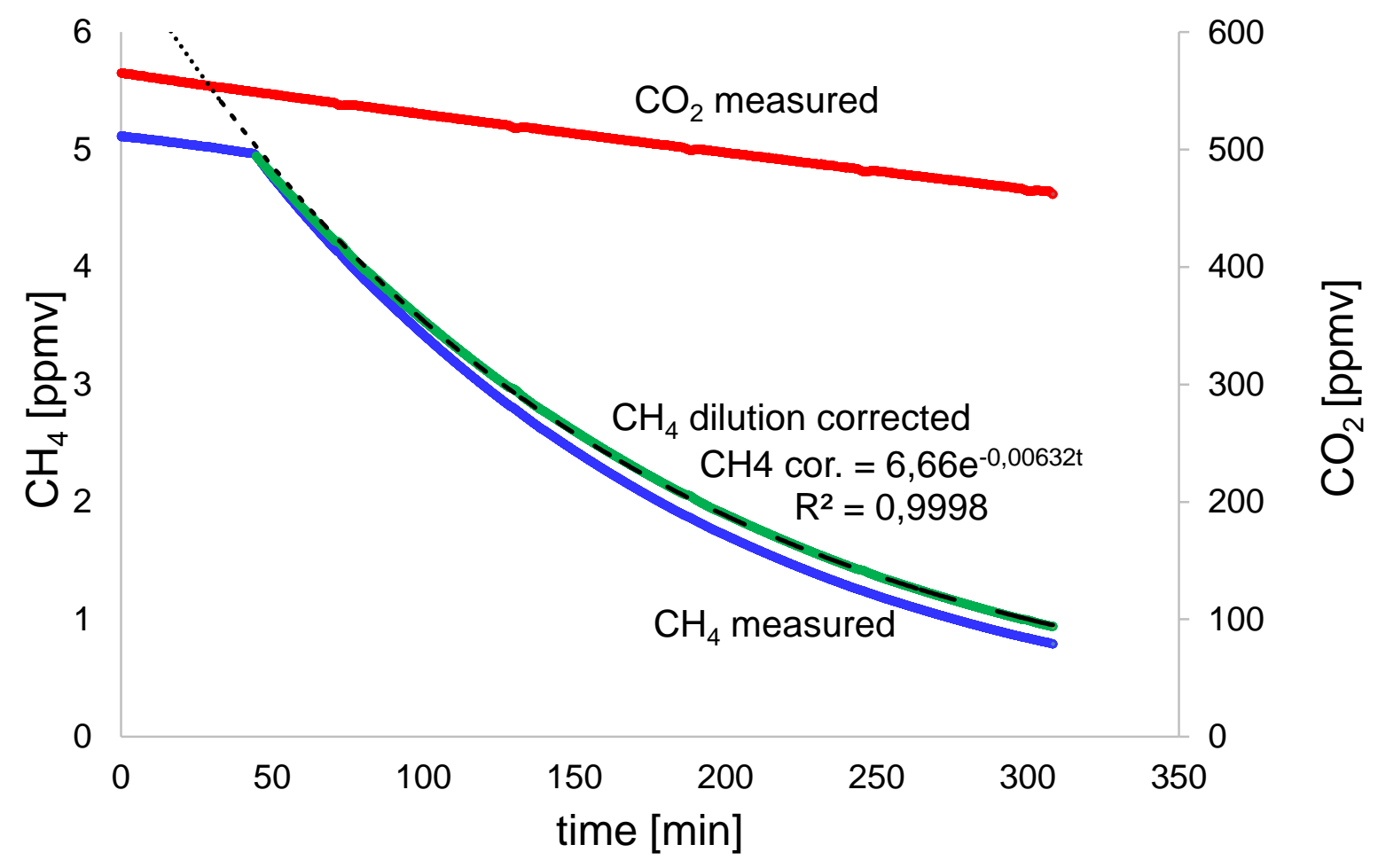

Figure S2: $\mathrm{CH}_{4}+\mathrm{OH}$ control experiment without canister sampling where ozone was continuously photolysed. The steady state ozone mixing ratio was about 5000 ppbv. The observed degradation rate of $\mathrm{CH}_{4}$ of $0.00632 \mathrm{~min}^{-1}=1.05 \mathrm{e}^{-4} \mathrm{~s}^{-1}$ corresponds to a level of $1.7 \times 10^{10} \mathrm{~cm}^{3} \mathrm{~s}^{-1}$ for $\mathrm{OH}$, using a rate constant of $5.7 \times 10^{-15} \mathrm{~cm}^{-3}$ at $293 \mathrm{~K}$ (taken from Burkholder et al., 2015). The blue and red lines show the measured $\mathrm{CH}_{4}$ and $\mathrm{CO}_{2}$ mixing ratios, respectively. The green line shows the dilution corrected $\mathrm{CH}_{4}$ mixing ratios using $\mathrm{CO}_{2}$ as inert tracer. 

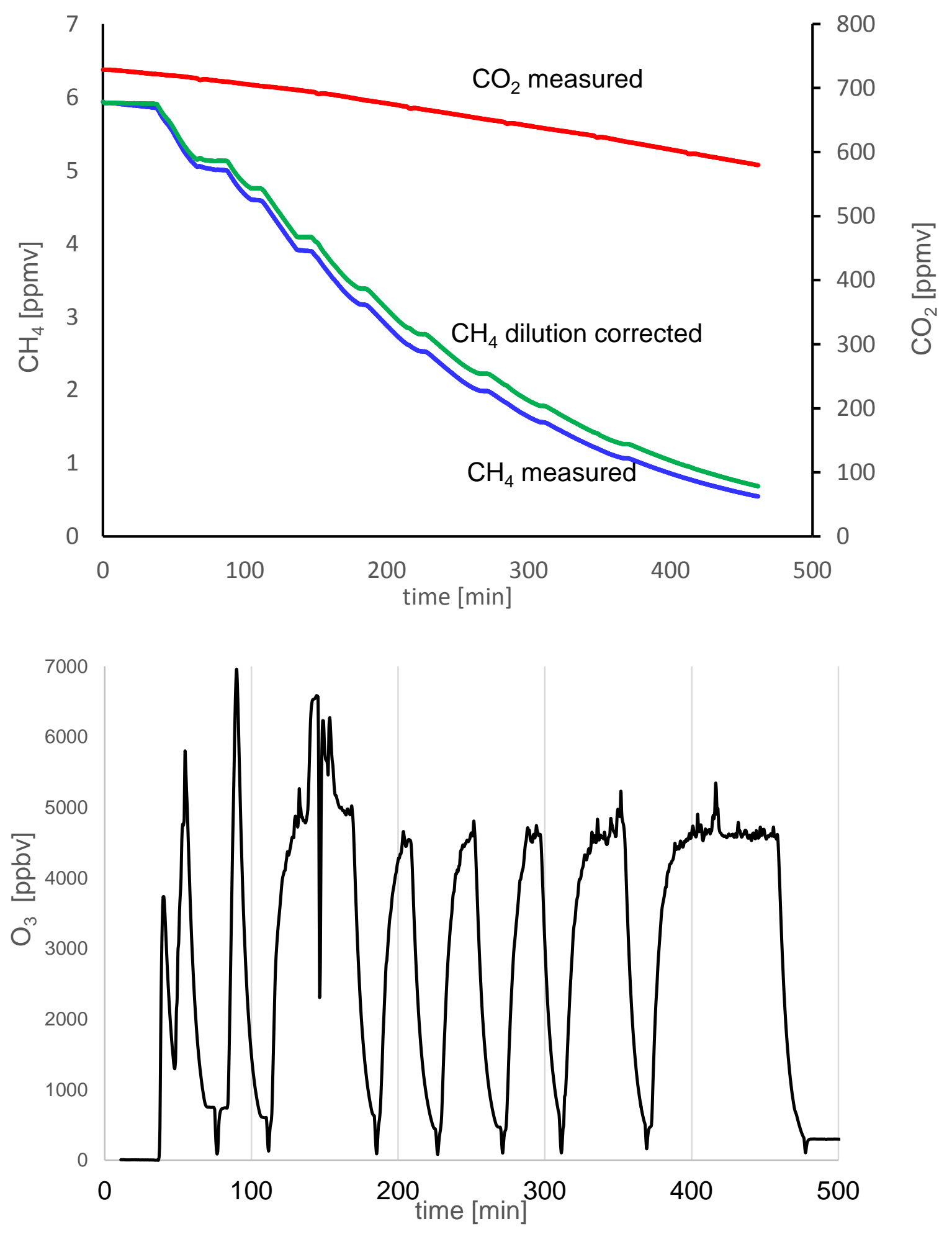

Figure S3: Upper row panel: $\mathrm{CH}_{4}+\mathrm{OH}$ degradation experiment for stable hydrogen isotope measurements. The measured $\mathrm{CH}_{4}$ mixing ratios (blue line) were corrected (green line) for dilution using $\mathrm{CO}_{2}$ (red line) as an inert tracer. We noted a small spectral interference $(<0.1 \%)$ in the $\mathrm{CO}_{2}$ signal arising from ozone. The lower row panel shows the corresponding steady state mixing ratios of ozone. Ozone and the TUV lamps were switched off from time to time to collect the canister samples. This interrupts the degradation of $\mathrm{CH}_{4}$ as shown in the upper panel. Mean ozone mixing ratios during photolysis were $4600 \mathrm{ppbv}$ and $3570 \mathrm{ppbv}$ on average over the entire experiment. 